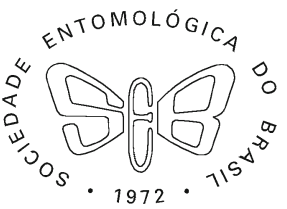

\title{
Special Section on Biological Control
}

\section{EMG Fontes, R LaUmann}

Embrapa Recursos Genéticos e Biotecnologia, Brasília, DF, Brazil
Biological control is regarded as an important ecosystem service that can significantly contribute to sustainable agriculture. Losey and Vaughan (2006) estimated at $\$ 5.9$ billion (2018 dollars) the economic value for the pest control provided by natural enemies in the USA alone. In recent years, scientists in the area of biocontrol in Latin America have been seeing a trend in the agricultural sector towards favoring biological control, which has motivated the edition of this special section in Neotropical Entomology. This special section originated from a call for papers, which was part of the Symposium on Biological Control, held in August 2019 in the city of Londrina, Brazil.

A five-member expert committee selected the articles that make up this special section, after each of them had been independently peer-reviewed. This set of articles is only a sample of the range of ongoing research in Latin America, reflecting the favorable environment for this technology in the region's agricultural sector, which is leaning towards more sustainable agriculture. Pest problems result from the ecological over simplicity of modern agricultural fields, planted in large monocultures and receiving frequent applications of broad-spectrum insecticides, which contribute to the outbreaks of herbivorous insect-pests typical of these systems (Pimentel 1961, Van Emden \& Williams 1974). In turn, less hostile environments for natural enemies, leading to species-rich communities of predators, parasitoids and insect pathogens, strengthen biological control.

To open this special section we have included a Forum article by A. Peñalver-Cruz et al 2019, discussing how stable and diverse agricultural fields provide farmers with ecological services, such as biological control. They present the status of the research on habitat manipulation in South America through the planning of diversified agricultural fields and the application of different agricultural practices that influence pest management through the conservation of natural enemies.

In the following set of scientific articles, one proposes the implementation of conservation biological control of disease vector mosquitoes by assessing the development and the predatory skills of Belostoma anurum (Herrich-Schäffer, 1948) (Hemiptera: Belostomatidae), an aquatic predator widely distributed in Neotropical region (Valbom et al 2019). Predation is also the subject of two other articles, one dealing with insecticide-resistant populations of a lady beetle (Lira et al 2019), and the other focusing on parasitism-mediated interactions between the ring-legged earwig and the sugarcane borer larvae (Nunes et al 2019), and the third identify molecular markers to to recognize Diaphorina citri Kuwayama, 1908 (Hemiptera: Liviidae) DNA in gut content of predators (Nanini et $a l)$ ). Five other articles dedicate to propose improved techniques for rearing and field releasing parasitoids, aiming at greater efficiency in biological control programs (Castellanos et al 2019, Gonzalez-Cabrera et al 2019, Krüger et al 2019, Pereira et al 2019, Queiroz et al 2019). One last article analyzes the taxonomic status and reports the variation in population density of the parasitoid Aphidius colemani (Dalman, 1820) (Braconidae: Aphidiinae), introduced in Southern Brazil in the 1960s to control wheat pest aphids (Santos et al).

\section{References}

Castellanos NL, Bueno AF, Haddi K, Silveira EC, Rodrigues HS, Hirose E, Smagghe G, Oliveira EE (2019) The fitness and economic benefits of rearing the parasitoid Telenomus podisi under fluctuating temperature regime. Neotrop Entomol https://doi.org/10.1007/s13744-01900717-1

Gonzalez-Cabrera J, Moreno-Carrillo G, Sanchez-Gonzalez JA, MendozaCeballos MY, Arredondo-Bernal HC (2019). Single and combined release of Trichopria drosophilae (Hymenoptera: Diapriidae) to control Drosophila suzukii (Diptera: Drosophilidae). Neotrop Entomol https:// doi.org/10.1007/s13744-019-00707-3

Krüger AP, Scheunemann T, Vieira JVA, Morais MC, Bernardi D, Nava DE, Garcia FRM (2019) Effects of extrinsic, intraspecific competition and host deprivation on the biology of Trichopria anastrephae (Hymenoptera: Diapriidae) reared on Drosophila suzukii (Diptera: Drosophilidae). Neotrop Entomol https://doi.org/10.1007/s13744019-00705-5 
Lira R, Nascimento DV, Torres JB, Siqueira, HAA (2019) Predation on diamondback moth larvae and aphid by resistant and susceptible lady beetle, Eriopis connexa. Neotrop Entomol https://doi.org/10.1007/ s13744-019-00702-8

Losey JE, Vaughan M (2006) The economic value of ecological serviced provided by insects. BioScience $56: 311-323$

Nunes GS, Ramalho DG, dos Santos NA, Truzi CC, Vieira NF, Cardoso CP, De Bortoli SA (2019) Parasitism-mediated interactions between the ring-legged earwig and sugarcane borer larvae. Neotrop Entomol https://doi.org/10.1007/s13744-019-00730-4

Peñalver-Cruz A, Alvarez-Baca JK, Alfaro-Tapia A, Gontijo, L, Lavandero, B (2019) Manipulation of agricultural habitats to improve conservation biological control in South America. Neotrop Entomol https://doi. org/10.1007/s13744-019-00725-1

Pereira FP, Reigada C, Diniz AJF, Parra JRP (2019) Potential of two Thrichogrammatidae species for Helicoverpa armigera control. Neotrop Entomol https://doi.org/10.1007/s13744-019-00730-4
Pimentel D (1961) Species diversity and insect population outbreaks. Ann Entomol Soc Am 54:76-86

Queiroz AP, Favetti BM, Hayashida R, Grande MLM, Neiva MM, Panizzi AR, Bueno AF (2019). Effect of the ages of parasitoid and host eggs on Telenomus podisi (Hymenopter: Platygastridae) parasitism. Neotrop Entomol https://doi.org/10.1007/s13744-019-00724-2

Valbon WR, Haddi, K Gutiérrez Y, Cruz FM, Azevedo KEX, Perez Campos JS, Salaro AL, Oliveira EE (2019) Life hystory traits and predatory performance of Belostoma anurum (Hemiptera: Belostomatidae), a biological control agent of disease vector mosquitoes. Neotrop Entomol https://doi.org/10.1007/s13744-019-00710-8

Van Emden HF, Williams GF (1974) Insect stability and diversity in agroecosystems. Annu Rev Entomol 19:455-475

Publisher's Note Springer Nature remains neutral with regard to jurisdictional claims in published maps and institutional affiliations. 